\title{
Kriteria Otentikasi Dokumen Elektronik dengan Weighted Product
}

\author{
Criteria for Authentication of Electronic Documents with Weighted Product
}

\author{
Alvhinia Meinda Amitaba*1, Ema Utami ${ }^{2}$, Hanif Al Fatta ${ }^{3}$ \\ ${ }^{1,2,3}$ Magister Teknik Informatika; Universitas Amikom Yogyakarta \\ 1, 2, 3 Yogyakarta, Indonesia \\ e-mail: *1alvhinia.1189@students.amikom.ac.id, 2ema.u@amikom.ad.id, \\ hanif.a@amikom.ac.id
}

\begin{abstract}
Abstrak - Dalam dunia nyata, untuk menjamin keaslian serta legalitas suatu dokumen digunakan tanda tangan. Tanda tangan ini merupakan suatu tanda yang bersifat unik milik seseorang dan digunakan untuk memberi pengesahan bahwa orang tersebut setuju dan mengakui isi dari dokumen yang ditandatangani. Untuk dokumen-dokumen elektronik pun dibutuhkan hal semacam ini. Oleh karena itu, diciptakan suatu sistem otentikasi yang disebut tanda tangan digital. Tanda tangan digital merupakan teknik yang sangat tepat digunakan untuk menjamin keaslian suatu dokumen serta menghindari adanya penyangkalan bahwa seseorang telah menandatangani suatu dokumen. Teknik ini jauh lebih canggih dan lebih efisien daripada tanda tangan yang dilakukan secara manual. Keamanan dan kerahasiaan data merupakan hal penting untuk mencegah penyalahgunaan data. Sebuah data dapat diamankan dengan cara melakukan penyandian terhadap isi data yang telah terverifikasi oleh Penyelenggara Sertifikasi Elektronik. Sistem verifikasi tanda tangan disediakan berdasarkan informasi sertifikasi tanda tangan yang dimiliki oleh seorang penandatangan untuk memverifikasi integritas dokumen elektronik. Pada penelitian ini dilakukan penentuan kriteria pada dokumen elektronik yang terbukti otentikasinya berdasarkan verifikasi dokumen elektronik yang telah dilakukan menggunakan kriteria yang telah ditentukan yaitu, confidentiality, integrity, authentication, non repudiation, lama verifikasi, validity sertifikat, termasuk keberhasilan verifikasi dokumen elektronik dengan metode Weighted Product. Dataset didapatkan dari olah data manual dengan beberapa macam skenario dokumen elektronik.
\end{abstract}

Kata kunci - Tanda Tangan Digital, Keamanan Informasi, Verifikasi, Weighted Product;

\begin{abstract}
In the real world, to ensure the authenticity and legality of documents used signatures. This signature is a mark made by a person and is used to authorize that person and approve the contents of the signed document. Even for electronic documents, this kind of thing is needed. Therefore, an approved system was created called a digital signature. Digital signatures are a very appropriate technique used to guarantee the authenticity of a document and avoid any denial that has been approved by a document. That technique is better than manual signatures. Data security and confidentiality are important to prevent data integration. Data can be secured by encoding data contents that have been verified by the Certification Authority. A signature verification system is provided based on signature certification information held by a signatory for the approval of the integrity of electronic documents. In this study, criteria were determined on electronic documents that were proven to be authenticated based on the verification of electronic documents that had been carried out using predetermined criteria, namely, confidentiality, integrity, authentication, nonrepudiation, length of verification, certificate validity, including the success of electronic document verification using the Weighted Product method. The dataset is obtained from manual data processing with several kinds of electronic document scenarios.
\end{abstract}

Keywords - Digital Signatures, Information Security, Verification, Weighted Product;

\section{PENDAHULUAN}

Penelitian ini berkaitan dengan verifikasi tanda tangan digital. Lebih khusus lagi, penemuan ini berkaitan dengan penentuan kriteria dokumen elektronik yang telah terbukti otentik dengan dilakukannya verifikasi tanda tangan digital yang berhubungan dengan penerbit sertifikat digital. Dalam lingkungan pesan tertulis atau dokumen, pesan dapat ditandatangani secara digital untuk mengidentifikasi pembuat pesan dan untuk memastikan bahwa setelah menerima pesan tidak dimodifikasi saat dalam perjalanan. Salah satu metode penandatanganan pesan secara digital adalah dengan menggunakan Public Key Infrastructure(PKI).

Digital signature bekerja dengan cara meringkas isi dari dokumen yang diamankan, kemudian disandikan dengan suatu algoritma 
kriptografi, dan hasilnya disisipkan ke dalam dokumen tersebut. Sehingga dokumen digital dan tanda tangan digital tersebut akan selalu ada bersama-sama dalam satu file. Terdapat tiga proses utama dalam digital signature, yaitu proses mendapatkan ringkasan isi dokumen, proses menyandikan ringkasan, dan terakhir adalah proses menyisipkan ringkasan terenkripsi. Proses meringkas suatu isi dokumen dapat dilakukan dengan menggunakan fungsi hash. Output dari fungsi hash disebut nilai hash. Fungsi hash adalah salah satu alat penting dalam bidang kriptografi dan digunakan untuk mencapai sejumlah tujuan keamanan seperti keaslian, tanda tangan digital, digital steganography, dan lainnya[1].

Penelitian terdahulu oleh Guy Dolev tahun 2019 dengan menangkap gambar dokumen untuk diautentikasi dari pemindai dan meningkatkan gambar yang diambil, dan menggunakan prosesor untuk mengidentifikasi dan memotong bagian gambar. Tujuan penelitian ini untuk mengautentikasi dokumen dapat memeriksa integritas bahan dokumen, integritas tanda dokumen, konsistensi data dalam dokumen tanpa adanya kriteria yang lain. Hasil yang diperoleh menunjukkan bahwa sistem memiliki akurasi sebesar 70\%[2].

Penelitian selanjutnya oleh Gordon Romney, Pedro (Kepa) Zubeldia tahun 2017. Penelitian bertujuan untuk mengidentifikasi tanda tangan digital pada dokumen elektronik dengan pemilik kunci pribadi yang terkait dengan kunci publik tertentu. Selain itu, tanda tangan digital dapat digunakan untuk menentukan apakah suatu dokumen elektronik telah diubah selama pengiriman dokumen dari pengirim ke penerima. Sistem membuktikan verifikasi tanda tangan digital menggunakan kunci publik yang disediakan oleh pengguna. Setelah menyaksikan pengguna menandatangani secara digital dokumen elektronik menggunakan kunci pribadi pengguna, kemudian memverifikasi bahwa kunci publik yang diberikan kepada autentikator oleh pengguna sesuai dengan kunci pribadi yang digunakan oleh pengguna untuk menghasilkan tanda tangan digital, dan telah memverifikasi identitas pengguna[3].

Penelitian selanjutnya oleh Kezia Tirza Naramessakh dan Cahyo Priyanto tahun 2019. Penelitian bertujuan untuk mempercepat proses pengambilan keputusan yang mampu menangani kelayakan pemberian kredit pensiun serta menghemat waktu dan biaya dalam penentuan kelayakan kredit. Metode penyelesaian yang digunakan adalah Weighted Product yang merupakan salah satu metode penyelesaian untuk masalah Multi Attribute Decision Making (MADM). Dengan menggunakan metode Weighted Product (WP) akan mencari bobot untuk setiap kriteria, kemudian dilakukan proses peringkat yang akan menentukan alternatif optimal dari Pensiunan. hasil penelitian ini telah menunjukkan bahwa penerapan metode Weighted Product dapat membantu dan mendapatkan hasil dalam menentukan Pensiun yang berhak untuk diberikan pemberian kredit yaitu pada alternatif P7 (Renni) dengan berdasarkan kriteria-kriteria atau syarat yang sudah ditentukan[4].

Pada penelitian yang dilaksanakan oleh Syifa Afifah Fitriani dan Rosa Ariani Sukamto menyatakn bahwa Weighted Product(WP) dan TOPSIS adalah dua metode yang banyak digunakan untuk membantu dalam pengambilan keputusan. Karena penelitian tentang perbandingan kedua metode tampaknya belum luas, penelitian ini bertujuan untuk membandingkan kedua metode dengan melihat kompleksitas dan akurasinya. Pengukuran kompleksitas mereka dilakukan dengan menggunakan Kompleksitas Siklomatik dan akurasinya dihitung berdasarkan tingkat kesalahan yang diperoleh. Hasil penelitian menunjukkan bahwa meskipun metode TOPSIS memiliki tingkat kompleksitas yang lebih tinggi, yaitu 8 dibandingkan dengan metode WP 5, TOPSIS memiliki tingkat akurasi yang lebih tinggi yaitu 73\% dibandingkan dengan WP $67 \%$. Oleh karena itu, metode TOPSIS lebih baik[5].

Penelitian oleh M Ahsan dan N Indawati menyatakan bahwa Pengambilan Keputusan Multi Atribut (MADM) digunakan dalam pembuatan sistem pendukung keputusan menggunakan Weighted Product(WP) untuk mendefinisikan anak Multiple Intelligence dengan 8 kecerdasan dan 8 kriteria dengan bobot yang ditentukan. Data diuji berdasarkan data siswa baru yang telah mendaftar di SMP Negeri 3 Kepanjen dengan jumlah data 226 siswa yang telah mendaftar dan mengisi kuesioner (indikator) yang telah disediakan melalui www.teskecerdasan.com. Hasil penelitian ini adalah grafik yang telah diberi peringkat 
berdasarkan desa metode Weighted Product (WP)[6].

Berdasarkan pemaparan diatas, maka penelitian ini akan membahas tentang implementasi metode Weighted Product untuk pemilihan kriteria atau kategori sebuah dokumen elektronik yang terbukti valid dan otentik pada penelitian ini dengan memperhatikan kriteria yang telah ditentukan yaitu, confidentiality, integrity, authentication, non repudiation, lama verifikasi, validity sertifikat, termasuk keberhasilan verifikasi dokumen elektronik.

\section{LANDASAN TEORI}

Tanda tangan digital adalah sebuah teknik dalam kriptografi yang dapat digunakan untuk menandatangani dokumen digital. Tanda tangan digital juga merupakan hasil dari diberlakukannya teknik kriptografi terhadap isi dokumen asli. Kriptografi bertujuan agar informasi yang bersifat rahasia dan dikirim melalui suatu jaringan, seperti LAN atau internet, tidak dapat diketahui dan dimanfaatkan oleh orang lain atau pihak yang tidak berkepentingan[7].

Penerapan teknologi komputer sebagai salah satu media penyimpanan dan komunikasi menjadi suatu kebutuhan penting yang berhubungan dengan sistem informasi. Berbagai macam data atau informasi yang diperoleh akan dimanfaatkan untuk berbagai kepentingan. Pertukaran data atau informasi sudah semakin mudah dilakukan dengan atau tanpa melalui media fisik. Pada proses pertukaran data atau informasi terdapat beberapa aspek penting yang perlu diperhatikan, yaitu: kerahasiaan, integritas data, autentikasi dan non repudiasi. Namun terkadang aspek tersebut kurang diperhatikan, sehingga memungkinkan adanya pencurian atau pemalsuan data. Oleh karena itu dibutuhkan suatu proses pengkodean data atau informasi sebelum dilakukan proses pengiriman. Sehingga data atau informasi yang dikirim terjaga kerahasiaannya dan tidak mudah untuk dapat mengubahnya. Misalnya, dengan membubuhkan tanda tangan digital yang terenkripsi pada suatu data atau informasi sehingga memenuhi aspek-aspek yang dibutuhkan[8].

Untuk mengamankan suatu dokumen dari modifikasi yang tidak sah, digunakan suatu metode yang disebut dengan digital signature. Tanda tangan digital harus memiliki fungsi yang sama dengan tanda tangan konvensional, yaitu dapat menjamin integrity, authenticity, dan nonrepudiation. Tanda tangan digital dibangkitkan dari hash terhadap pesan. Tanda tangan digital berlaku seperti tanda tangan dokumen kertas, tanda tangan digital ditambahkan (append) pada pesan[9].

Dokumen yang hendak dikirim terlebih dahulu dikenai fungsi hash sehingga menjadi bentuk yang ringkas yang disebut dengan message digest. Kemudian, message digest dienkripsi menggunakan algoritma kriptografi kunci-publik, kunci privat milik penandatangan atau pengirim dokumen akan digunakan untuk melakukan enkripsi message digest. Hasil dari enkripsi inilah yang disebut sebagai tanda tangan digital (digital signature) [10].

Proses utama pada tanda tangan digital terdiri atas dua proses, yaitu proses signing (tanda tangan) dan verifikasi. Proses signing dilakukan dengan mengubah sebuah isi dokumen menjadi message digest dan mengenkripsinya menggunakan algoritma kriptografi RSA. Sementara, proses verifikasi dilakukan dengan membandingkan hasil dekripsi isi dokumen yang diterima (ciphertext) dengan message digest dari isi dokumen sebenarnya. Algoritma Kriptografi dari setiap kriptografi klasik selalu terdiri dari dua bagian yaitu enkripsi dan dekripsi[11].

Identifikasi dan verifikasi awal pengguna dapat didukung oleh sejumlah fitur. Otentikasi biometrik adalah yang utama faktor, tetapi kadang-kadang didukung dengan memiliki seperti token RFID, yang menyimpan template biometrik. Otentikasi berbasis terutama dilakukan dengan kata sandi grafis tetapi terkadang juga dikombinasikan dengan fitur biometric seperti mengetik karakteristik kata sandi[12].

\section{METODE}

Pada tahap penelitian dan pengumpulan informasi, dapat dianggap sebagai tahap awal penelitian. Tahap ini termasuk studi literatur yang terkait dengan masalah yang sedang dipelajari, dan persiapan untuk merumuskan kerangka penelitian. Pada tahap perencanaan penelitian, kegiatan-kegiatan seperti: (a) menentukan tujuan penelitian, (b) memperkirakan dana, personel dan waktu, (c) merumuskan kualifikasi peneliti dan peran mereka dalam penelitian[13]. Pemilihan kriteria atau kategori dokumen elektronik menggunakan metode Weighted Product yang terbukti valid dan otentik pada saat melakukan verifikasi dokumen elektronik ini memiliki 
beberapa tahapan yang terlampir pada Gambar 1 dibawah ini :

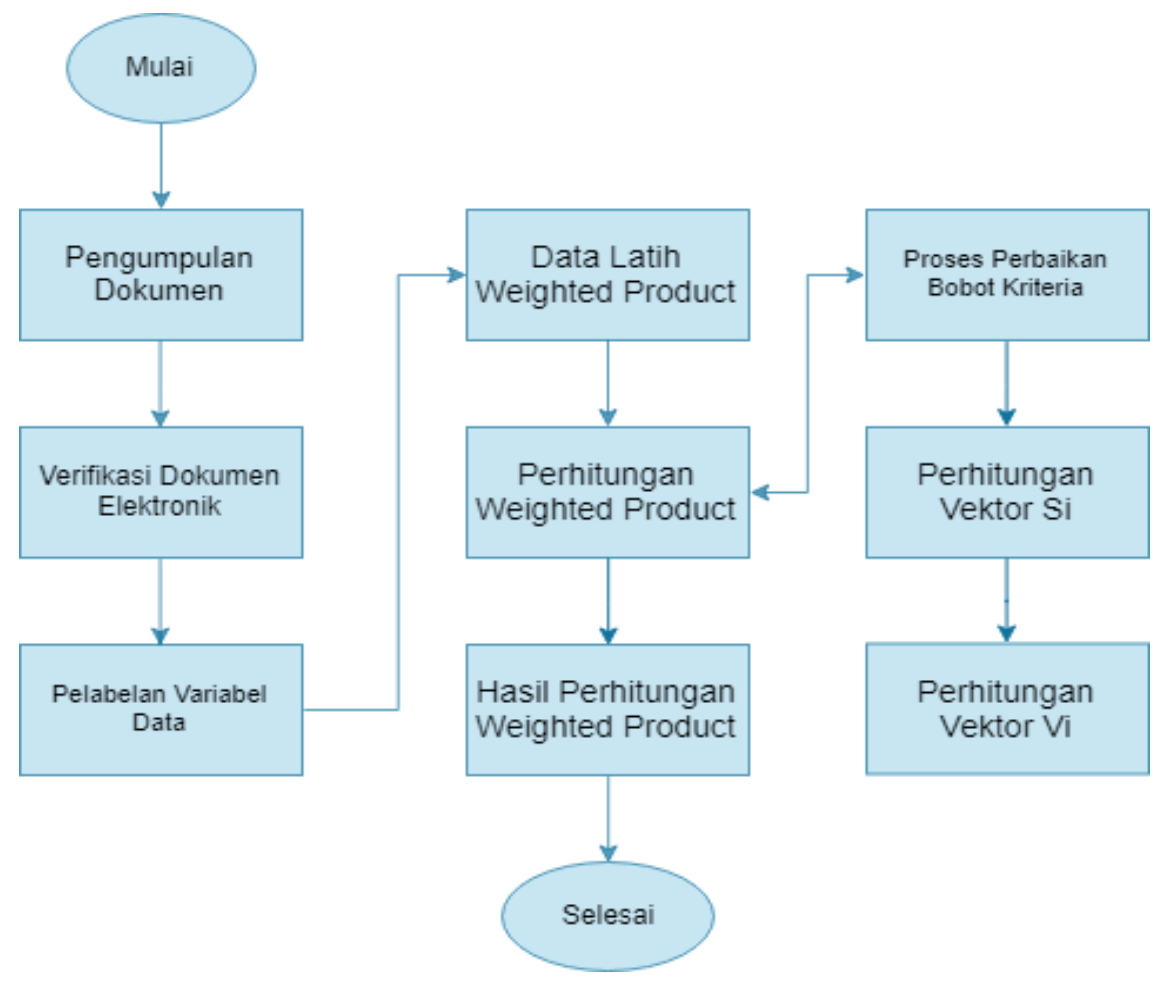

Gambar 1. Diagram Aliran Sistem

1. Pengumpulan dokumen elektronik

Data yang dikumpulkan adalah dokumen elektronik dengan format pdf yang didapatkan dari pengolahan data secara mandiri dan data sampel yang telah dibagikan dari suatu organisasi.

2. Verifikasi Dokumen Elektronik menggunakan platform Certificate Authority

1) Upload dokumen

2) Hitung lama proses verifikasi

3) Analisa tanda tangan digital yang ada pada dokumen elektronik

3. Pelabelan variabel pada data yang diperoleh berdasarkan kriteria atau parameter otentikasi dokumen elektronik yang sudah ditentukan :

\section{1) Confidentiality}

Dokumen memiliki kriptografi untuk menjaga kerahasiaan pesan dengan cara mengenkripsinya ke dalam bentuk yang tidak mempunyai makna.

2) Integrity

Hal ini berkaitan dengan keutuhan (integrity) pesan. Dengan kata lain, masalah ini dapat diungkapkan sebagai pertanyaan: "Apakah pesan yang diterima tidak mengalami perubahan (modifikasi)?"

3) Authentication
Hal ini berkaitan dengan kebenaran identitas pengirim. Dengan kata lain, masalah ini dapat diungkapkan sebagai pertanyaan: "Apakah pesan yang diterima benar-benar berasal dari pengirim yang sesungguhnya?"

4) Non Repudiation

Pengirim tidak dapat menyangkal (berbohong) tentang isi pesan yang ia kirim.

5) Lama Verifikasi

Jumlah waktu proses verifikasi dokumen elektronik dalam hitungan berapa per second/detik.

6) Keberhasilan Verifikasi

Proses verifikasi berhasil atau gagal.

7) Validity Sertifikat

Sertifikat Pengguna atau penandatangan dokumen yang diterbitkan oleh Certificate Autority terdeteksi valid atau invalid.

4. Data Latih Weighted Product

Data yang sudah didapatkan dari proses verifikasi dan sudah diberikan label.

5. Perhitungan Weighted Product 


\section{a. Normalisasi/Perbaikan Bobot}

$W_{j}=\frac{W_{j}}{\Sigma W_{j}}$

Melakukan normalisasi/perbaikan bobot untuk menghasilkan nilai dimana $1,2, \ldots . ., \mathrm{n}$ adalah banyak alternatif. Menentukan kategori dari masing-masing kriteria yang termasuk dalam kriteria keuntungan atau kriteria biaya[14].

\section{b. Menentukan Nilai Vektor $S$}

$S i=\prod_{i=1} n X i j w j$, dengan $i=1,2, \ldots, m \ldots$ (2)

Keterangan:

$\Pi$ : product

$\mathrm{Si}$ : skor / nilai dari setiap alternatif

$X i j$ : nilai alternatif ke- $i$ terhadap atribut ke- $j$

$W j$ : bobot dari setiap atribut atau kriteria

$n$ : Banyaknya kriteria.

Menentukan nilai vektor S dengan

mengalikan seluruh kriteria dengan alternatif hasil normalisasi/perbaikan bobot yang

berpangkat positif untuk kriteria keuntungan dan yang berpangkat

negatif untuk kriteria biaya.

\section{c. Menentukan Nilai Vektor V / Perangkingan}

$$
V i=\frac{\Perp_{j=1} n X i j W_{j}}{\prod_{j=1} n\left[x_{j}^{j}\right) W j}
$$

Keterangan :

$V$ : Preferensi alternatif dianalogikan sebagai vektor $V$

$x$ : Nilai Kriteria

$w:$ Bobot kriteria/subkriteria

$i$ : Alternatif

$j$ : Kriteria

$n$ : Banyaknya kriteria

*: Banyaknya kriteria yang telah dinilai pada vektor $S$

Menentukan nilai vektor $V$ yang akan

digunakan untuk perangkingan dari masing-

masing jumlah

nilai vektor $\mathrm{S}$ dengan jumlah seluruh nilai vektor $S$.

6. Hasil Perhitungan Weighted Product

Hasil dari perhitungan akan dirangking dan didapatkan alternatif yang paling maksimal sehingga dapat dicapai keputusan dalam menentukan kriteria dokumen elektronik yang otentik.

\section{Pengambilan Keputusan}

Keputusan akan diambil setelah setelah proses perhitungan selesai dan mendapatkan jenis kriteria yang paling maksimal.

Untuk tujuan tertentu, sebagian besar pembuat keputusan mempertimbangkan manfaat atau rasio biaya. Menghadapi kebutuhan untuk mengandalkan seperangkat sistem yang mampu menyelesaikan masalah secara efisien dan efektif, yang kemudian disebut sebagai sistem pendukung keputusan (DSS)[15].

\section{HASIL DAN PEMBAHASAN}

\subsection{Hasil}

4.1.1 Pengumpulan data terkait proses verifikasi dokumen elektronik

Data yang dikumpulkan adalah dokumen elektronik dengan format pdf yang didapatkan dari pengolahan data secara mandiri dan data sampel yang telah dibagikan dari suatu organisasi sebanyak 100 dokumen untuk dijadikan data latih.

4.1.2 Verifikasi Dokumen Elektronik menggunakan platform Certificate Authority

1. Upload dokumen

2. Hitung lama proses verifikasi

3. Analisa tanda tangan digital yang ada pada dokumen elektronik

4.1.3 Pelabelan variabel pada data yang diperoleh berdasarkan kriteria atau parameter otentikasi dokumen elektronik yang sudah ditentukan :

1) Confidentiality

Dokumen memiliki kriptografi untuk menjaga kerahasiaan pesan dengan cara mengenkripsinya ke dalam bentuk yang tidak mempunyai makna.

2) Integrity

Hal ini berkaitan dengan keutuhan (integrity) pesan. Dengan kata lain, masalah ini dapat diungkapkan sebagai pertanyaan: "Apakah pesan yang diterima tidak mengalami perubahan (modifikasi)?"

3) Authentication

Hal ini berkaitan dengan kebenaran identitas pengirim. Dengan kata lain, masalah ini dapat diungkapkan sebagai pertanyaan: "Apakah pesan yang diterima benar-benar berasal dari pengirim yang sesungguhnya?" 
4) Non Repudiation

Pengirim tidak dapat menyangkal (berbohong) tentang isi pesan yang ia kirim.

5) Lama Verifikasi

Jumlah waktu proses verifikasi dokumen elektronik dalam hitungan berapa per second/detik.

6) Keberhasilan Verifikasi

Proses verifikasi berhasil atau gagal.

7) Validity Sertifikat
Sertifikat Pengguna atau
penandatangan dokumen yang diterbitkan oleh Certificate Autority terdeteksi valid atau invalid.

\subsubsection{Data Latih Weighted Product}

Data yang sudah didapatkan dari proses verifikasi dan sudah diberikan label yang ditunjukan pada tabel 1 .

Tabel 1. Data set yang sudah di label

\begin{tabular}{cccccccc}
\hline \multirow{2}{*}{ No } & \multicolumn{7}{c}{ Kriteria } \\
\cline { 2 - 8 } & Confidentiality & Authentication & Integrity & $\begin{array}{c}\text { Non } \\
\text { Repudiation }\end{array}$ & $\begin{array}{c}\text { Lama } \\
\text { Verifikasi }\end{array}$ & $\begin{array}{c}\text { Validity } \\
\text { Certificate }\end{array}$ & $\begin{array}{c}\text { Keberhasilan } \\
\text { Verifikasi }\end{array}$ \\
\hline 1 & 2 & 1 & 4 & 1 & 1 & 1 & 1 \\
\hline 2 & 3 & 1 & 1 & 1 & 2 & 2 & 2 \\
\hline 3 & 3 & 1 & 2 & 2 & 3 & 1 & 1 \\
\hline 4 & 2 & 1 & 2 & 2 & 2 & 1 & 1 \\
\hline 5 & 4 & 3 & 3 & 4 & 4 & 2 & 2 \\
\hline$\ldots$ & $\ldots$ & $\ldots$ & $\ldots$ & $\ldots$ & $\ldots$ & $\ldots$ & $\ldots$ \\
\hline 98 & 4 & 2 & 2 & 3 & 2 & 2 & 2 \\
\hline 99 & 1 & 2 & 2 & 4 & 2 & 1 & 1 \\
\hline 100 & 2 & 3 & 4 & 1 & 2 & 2 & 2 \\
\hline
\end{tabular}

Setelah diketahui data set yang di label, maka dimasukan ke dalam sistem terkait data latih seperti pada Gambar 2.

\begin{tabular}{|c|c|c|}
\hline Alternatif $\quad \downarrow \mathbb{E}$ & $\downarrow \uparrow$ & Nilai $\quad 11$ \\
\hline Alternatif 1 - Document blank & Kriteria 3 - Integrity(Keaslian) & 1 \\
\hline Alternatif 1 - Document blank & Kriteria 5 - Lama Verifikasi & 1 \\
\hline Alternatif 1 - Document blank & Kriteria 7 - Keberhasilan Verifikasi & 1 \\
\hline Alternatif 1 - Document blank & Kriteria 1 - Confidentiality(Kerahasiaan) & 4 \\
\hline Alternatif 1 - Document blank & Kriteria 2 - Authentication(Keabsahan) & 2 \\
\hline Alternatif 1 - Document blank & Kriteria 4 - Non Repudiation(Anti Penyangkalan) & 2 \\
\hline Alternatif 1 - Document blank & Kriteria 6-Validity Ceritificate & 1 \\
\hline Alternatif 10 & Kriteria 3 - Integrity(Keaslian) & 1 \\
\hline
\end{tabular}

Gambar 2. Data Latih 
4.1.5 Perhitungan Weighted Product

a. Penentuan Kriteria

Penginputan tipe kriteria ke sistem sesuai dengan yang telah ditentukan berdasarkan cost dan benefit seperti pada Gambar 3.

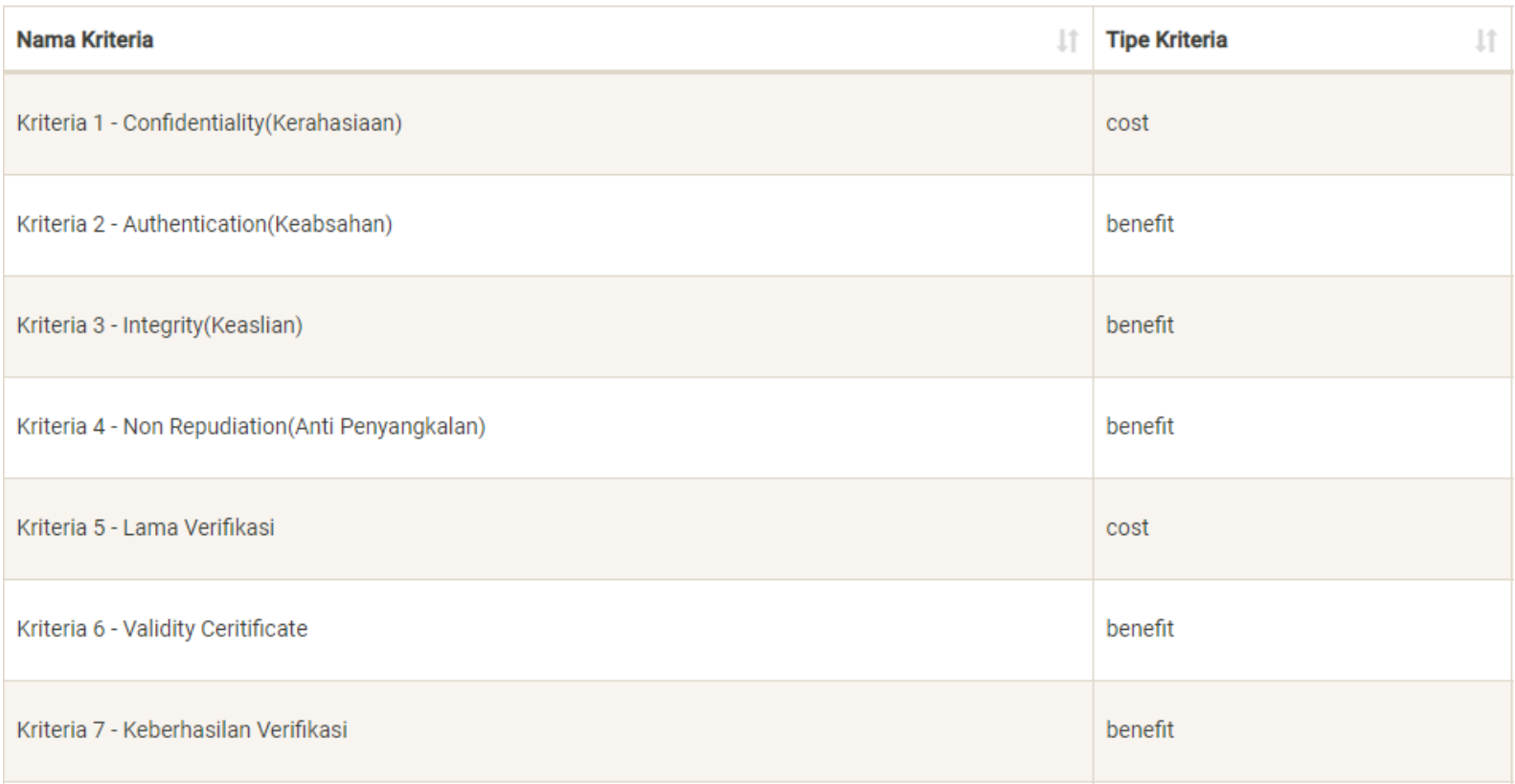

\section{Gambar 3. Kriteria}

\section{b. Normalisasi/Perbaikan Bobot}

Penginputan nilai bobot ke sistem dan secara otomatis sistem akan menghitung hasil dari perbaikan bobot atau normalisasi. Nilai bobot diinputkan berdasarkan kriteria yang telah disediakan pada menu kriteria sebelumnya. Penginputan nilai bobot seperti pada Gambar 4.

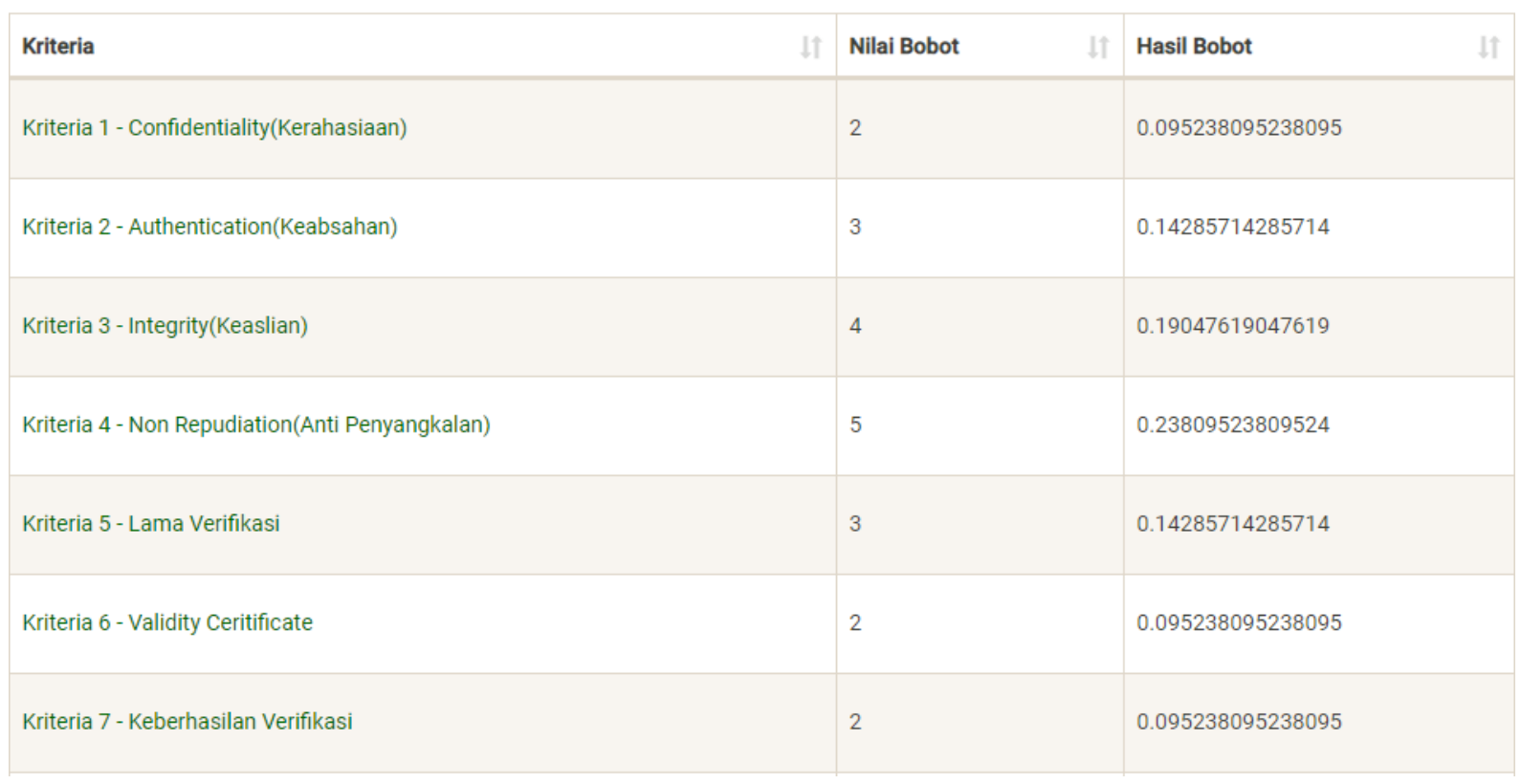

Gambar 4. Perbaikan Bobot 


\section{c. Menentukan Nilai Vektor $S$ dan Menentukan Nilai Vektor V / Perangkingan}

Langkah terakhir yaitu oenentuan nilai vektor $\mathrm{S}$ dan vektor $\mathrm{V}$ yang sudah di rangking berdasarkan nilai maksimal seperti pada Gambar 5.

\begin{tabular}{|l|l|l|}
\hline Nama Alternatif & Vektor S & Vektor V \\
\hline Alternatif 5 - Document signed with Digital Signature issued by Certification Authority & 1.6458091217492399 & 0.026024263953618 \\
\hline Alternatif 8 & 1.54067111956153 & 0.024361775221279 \\
\hline Alternatif 6 & 1.3492444805076578 & 0.021334852283097 \\
\hline Alternatif 9 & 1.3798567033941447 & 0.020785934594813 \\
\hline Alternatif 3 - Document signed by Adobe & 1.256798162418235 & 0.019873050090057 \\
\hline Alternatif 7 & 1.1699308127586912 & 0.018499465020794 \\
\hline Alternatif 4 - Document signed with Digital Signature issued by Certification Authority and Adobe & 1.141140309994045 & 0.01804421681892 \\
\hline
\end{tabular}

Gambar 5. Nilai S dan V

5 Hasil Perhitungan Weighted Product

Hasil dari perhitungan dari sistem yang sudah dirangking dan didapatkan alternatif yang paling maksimal yaitu alternatif 5 dengan jenis dokumen yang dimiliki adalah dokumen yang memiliki nilai kriteria dokumen confidentiality 4 , authentication 3 , integrity 3, non repudiation 4, lama verifikasi 4 , validity sertifikat 2 , dan keberhasilan verifikasi 2 , sehingga dapat dicapai keputusan dalam menentukan kriteria dokumen elektronik yang otentik.

6 Pengambilan Keputusan

Keputusan yang dapat diambil adalah setelah proses perhitungan selesai dan mendapatkan jenis kriteria yang paling maksimal. Maka, dapat diketahui bahwa verifikasi dokumen elektronik dengan kriteria yang telah ditentukan dapat mempengaruhi otentikasi dokumen.

\section{KESIMPULAN}

Dari hasil penelitian terkait penentuan kriteria untuk mengetahui otentikasi dokumen elektronik dengan verifikasi pada sistem Penyelenggara Sertifikasi Elektronik(Certificate Authority) yang paling berpengaruh diantara kriteria yang telah ditentukan, menunjukan bahwa kriteria confidentially, integrity dan authentication yang paling berpengaruh untuk penentuan otentikasi dokumen dengan pembuktian menggunakan alternatif 5 yaitu dokumen yang diverifikasi sudah menggunakan tanda tangan digital dengan sertifikat yang telah diterbitkan oleh Certificate Authority dengan hasil Vektor S sebesar 1.6458091217492399 dan Vektor V sebesar 0.026024263953618 .

\section{DAFTAR PUSTAKA}

[1] L. Refialy, E. Sediyono, and A. Setiawan, "Pengamanan Sertifikat Tanah Digital menggunakan Digital Signature SHA-512 dan RSA," J. Tek. Inform. dan Sist. Inf., vol. 1, no. 3, pp. 229-234, 2015, doi: 10.28932/jutisi.v1i3.400.

[2] P. A. Publication, "Ind ( 12 )," 2019.

[3] S. L. City, P. Examiner, and B. E. Gregory, "United States Patent," 1999.

[4] K. T. Naramessakh and C. Prianto, "Otomatisasi Keputusan Pemberian Kredit Pensiun Menggunakan Metode Weighted Product," Efisiensi - Kaji. Ilmu Adm., vol. 16, no. 1, pp. 33-48, 2019, doi: 10.21831/efisiensi.v16i1.24475.

[5] S. A. F. and R. A. S. N. S. Fitriasari, "Comparison of weighted product method and technique for order preference by similarity to ideal solution method: Complexity and accuracy," 3rd Int. Conf. Sci. Inf. Technol., pp. 453-458, 2017. 
[6] M. Ahsan and N. Indawati, "Implementation weighted product method to determine multiple intelligence child," J. Phys. Conf. Ser., vol. 1375, no. 1, 2019, doi: 10.1088/17426596/1375/1/012038.

[7] A. Arief and R. Saputra, "Implementasi Kriptografi Kunci Publik dengan Algoritma RSA-CRT pada Aplikasi Instant Messaging," Sci. J. Informatics, vol. 3, no. 1, pp. 46-54, 2016, doi: 10.15294/sji.v3i1.6115.

[8] I. Algoritma, R. S. A. Rivest, D. File, J. K. Azhar, and S. Yuliany, "Implementasi Algoritma RSA ( Rivest , Shamir dan," no. December, 2019.

[9] O. K. Sulaiman, M. Ihwani, and S. F. Rizki, "Model Keamanan Informasi Berbasis Tanda Tangan Digital Dengan Data Encryption Standard (Des) Algorithm," InfoTekJar (Jurnal Nas. Inform. dan Teknol. Jaringan), vol. 1, no. 1, pp. 14-19, 2016, doi: 10.30743/infotekjar.v1i1.82.

[10] M. Ray Rizaldy, "Perbandingan Tanda Tangan Digital RSA dan DSA Serta Implementasinya untuk Antisipasi Pembajakan Perangkat Lunak," 2009.

[11] Basri, "Kriptografi Simetris Dan Asimetris Dalam Perspektif Keamanan Data Dan Kompleksitas Komputasi," J. Ilm. Ilmu Komput., vol. 2, no. 2, pp. 1723, 2016, [Online]. Available: http://ejournal.fikom-unasman.ac.id.

[12] J. Schwartze, B. Haarbrandt, D. Fortmeier, R. Haux, and C. Seidel, "Authentication systems for securing clinical documentation workflows: A systematic literature review," Methods Inf. Med., vol. 53, no. 1, pp. 3-13, 2014, doi: 10.3414/ME12-01-0078.

[13] J. P. Vokasi et al., "Development of CSEUCLA evaluation model modified by using weighted product in order to optimize digital library services in higher education of computer in Bali," $J$. Pendidik. Vokasi, vol. 7, no. 3, pp. 275287, 2018, doi: 10.21831/jpv.v7i3.13370.

[14] D. M. Khairina, D. Ivando, and S. Maharani, “47-1-139-1-10-20160929," vol. 8, no. 1, pp. 1-8, 2016.

[15] Oktafianto et al., "Determining housing location using weighted product," Int. J. Eng. Technol., vol. 7, no. 4, pp. 35633568 , 2018 , doi: 